Details of participating centres can be found with the long version of this paper on bmj.com

Contributions: See bmj.com

Funding: Australia: Allen \& Hanbury, Australia; Belgium: Belgian Science Policy Office, National Fund for Scientific Research; France: Ministère de la Santé, Glaxo France, Institut Pneumologique d'Aquitaine, Contrat de Plan Etat-Région Languedoc-Roussillon, CNMATS, CNMRT (90MR/10, 91AF/ 6), Ministre délégué de la santé, RNSP, Ministère de l'Environnement (No 96115-EN96D4); Germany: GSF, Bundesminister für Forschung und Technologie, Bonn; Greece: Greek Secretary General of Research and Technology, Fisons, Astra, Boehringer-Ingelheim; India: Bombay Hospital Trust; Italy: Ministero dell'Univesità e della Ricerca Scientifica e Tecnologica, CNR, Regione Veneto Grant RSF No 381/05.93; New Zealand: Asthma Foundation of New Zealand, Lotteries Grant Board, Health Research Council of New Zealand; Norway: Norwegian Research Council project No 101422/310; Portugal: Glaxo Farmacêutica Lda, Sandoz Portugesa; Spain: Ministero Sanidad y Consumo FIS (grants 91/0016060/OOE-05E, 92/0319, 93/0393), Hospital General de Albacete, Hospital General Juan Ramón Jiménenz, Consejeria de Sanidad Principado de Asturias; Sweden: Swedish Medical Research Council, Swedish Heart Lung Foundation, Swedish Association against Asthma and Allergy, Swedish Society of Medicine, Astra, Glaxo-Wellcome, Boehringer-Ingelheim; Switzerland: Swiss National Science Foundation Grant 4026-28099; United Kingdom: National Asthma Campaign, British Lung Foundation, Department of Health, South Thames Regional Health Authority; United States: US Department of Health, Education and Welfare Public Health Service Grant No 2 S07 RR05521-28.

Competing interests: None declared.

1 Sporik R, Holgate ST, Platts-Mills TAE, Cogswell JJ. Exposure to house-dust mite allergen (Der p I) and the development of asthma in childhood. A prospective study N Engl J Med 1990:323:502-7.

2 Peat JK, Tovey E, Toelle BG, Haby MM, Gray EJ, Mahmic A, et al. House dust mite allergens. A major risk factor for childhood asthma in Australia. Am J Respir Crit Care Med 1996;153:141-6.

3 Ingram JM, Sporik R, Rose G, Honsinger R, Chapman MD, Platts-Mills TAE. Quantitative assessment of exposure to $\operatorname{dog}($ Can $\mathrm{f} \mathrm{I}$ ) and cat (Fel d I) allergens: relation to sensitization and asthma among children living in Los Alamos, New Mexico. J Allergy Clin Immunol 1995;96:449-56.
4 Sporik R, Ingram JM, Price W, Sussman JH, Honsinger RW, Platts-Mills TAE. Association of asthma with serum IgE and skin test reactivity to allergens among children living at high altitude. Tickling the dragon's breath. Am J Respir Crit Care Med 1995;151:1388-92.

5 Rosenstreich DL, Eggleston P, Kattan M, Baker D, Slavin RG, Gergen P, et al. The role of cockroach allergy and exposure to cockroach allergen in causing morbidity among inner-city children with asthma. N Engl J Med 1997;336:1356-63

6 Pollart SM, Reid MJ, Fling JA, Chapman MD, Platts-Mills TAE. Epidemiology of emergency room asthma in northern California: association with IgE antibody to ryegrass pollen. J Allergy Clin Immunol 1988;82:22430.

7 Halonen M, Stern DA, Wright AL, Taussig LM, Martinez FD. Alternaria as a major allergen for asthma in children raised in a desert environment. Am J Respir Crit Care Med 1997;155:1356-61.

8 O'Hollaren MT, Yunginger JW, Offord KP, Somers MJ, O'Connell EJ, Ballard DJ, et al. Exposure to an aeroallergen as a possible precipitating factor in respiratory arrest in young patients with asthma. $N$ Engl J Med 1991;324:359-63.

9 Black PN, Udy AA, Brodie SM. Sensitivity to fungal allergens is a risk factor for life-threatening asthma. Allergy 2000;55:501-4.

10 Targonski PV, Persky VW, Ramekrishnan V. Effect of environmental molds on risk of death from asthma during the pollen season.J Allergy Clin Immunol 1995;95:955-61.

11 Burney PGJ, Luczynska C, Chinn S, Jarvis D. The European Community respiratory health survey. Eur Respir J 1994;7:954-60.

12 European Commission, Directorate General XII. Protocol for the European Community respiratory health survey. Luxembourg: Office for Official Publications, 1993 (L-2920).

13 Ross MA, Curtis L, Scheff PA, Hryhorczuk DO, Ramakrishnan V, Wadden RA, et al. Association of asthma symptoms and severity with indoor bioaerosols. Allergy 2000;55:705-11.

14 Hopkinson L, O'Driscoll BR. Mould allergy is common in patients with severe asthma requiring multiple hospital admissions [abstract]. Eur Respir J 1997; 10 (suppl 25):28S.

15 Chinn S, Jarvis D, Luczynska C, Burney P. Individual allergens as risk factors for bronchial responsiveness in young adults. Thorax 1998;53:662-7.

16 Sunyer J, Soriano J, Anto JM, Burgos F, Pereira A, Payo F, et al. Sensitization to individual allergens as risk factors for lower FEV1 in young adults Int J Epidemiol 2000;29:125-30.

17 Newson R, Strachan K, Archibald E, Emberlin J, Hardaker P, Collier C. Effect of thunderstorms and airborne grass pollen on the incidence of acute asthma in England, 1990-94. Thorax 1997;52:680-5.

18 Sneller MR, Hayes HD, Pinnas JL. Frequency of airborne Alternaria spores in Tucson, Arizona over a 20-year period. Ann Allergy 1981;46:30-3.

19 Codina R, Lockey RF. Possible role of molds as secondary etiologic agents of the asthma epidemics in Barcelona, Spain. J Allergy Clin Immunol 1998;102:318-20.

(Accepted 4 April 2002)

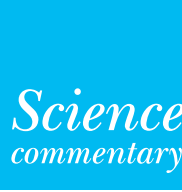

Abi Berger science editor, BM

\title{
Science commentary: Skin prick testing
}

Skin prick testing is conventionally used to investigate immediate type hypersensitivity to allergens in patients with rhinoconjunctivitis, contact urticaria, asthma, atopic eczema, and suspected food allergy. It is also a means of detecting allergen specific $\operatorname{IgE}$ and has the advantage of being relatively inexpensive, providing immediate results compared with measurement of serum allergen specific $\operatorname{IgE}$ by radioallergosorbent testing (RAST).

The technique used for skin prick testing involves puncturing the skin with a calibrated lancet $(1 \mathrm{~mm})$ held vertically, or a hypodermic needle or blood lancet at an angle of $45^{\circ}$, and introducing a drop of diluted allergen. All patients undergoing skin prick testing should also have a positive histamine control and negative diluent (saline) control test included. An itchy weal should develop at the histamine puncture site within 10 minutes. Test solutions are standardised to give a mean weal diameter of $6 \mathrm{~mm}$. The maximum or mean diameter of the weals to various allergens should be read at 15 minutes. A weal of $3 \mathrm{~mm}$ or more in diameter is generally considered to represent a positive response (indicating sensitisation to the allergen). The negative control is important because it excludes the presence of dermographism, which if present makes the tests difficult to interpret.

The relevance of skin prick testing should be interpreted in the context of the patient's history. Positive results can occur in people without symptoms and, similarly, false negative results may occur. "Blanket" allergy testing (whether by skin prick testing or serological methods) can give false positive results and, particularly in the case of foods can lead to unnecessary dietary restrictions. Standardised solutions to a wide range of allergens are available commercially. For more labile allergens (such as those found in fruit and vegetables) fresh produce should be used. Skin prick tests to aeroallergens are generally considered safe, but intramuscular adrenaline should be available and full resuscitation facilities are needed when test are carried out with other allergens such as foods and natural rubber latex. 